\title{
ANALISA FAKTOR-FAKTOR YANG MEMPENGARUHI HARGA DAN PERKEMBANGAN SAHAM SYARI'AH DI INDONESIA
}

\author{
Eka Sri Wahyuni \\ Fakultas Syariah dan Ekonomi Islam \\ Institut Agama Islam Negeri Bengkulu
}

\begin{abstract}
ABSTRAK
Eka Sri Wahyuni; Tujuan penelitian ini untuk mengetahui faktor - faktor yang mempengaruhi harga dan perkembangan saham syari'ah di Indonesia. Metode dalam penelitian ini menggunakan studi kepustakaan. Hasil dalam penelitian ini adalah pergerakan harga saham dipengaruhi oleh banyak faktor. Ada faktor yang bersifat mikro, ada juga yang bersifat makro. Selain itu, faktor-faktor yang mempengaruhi harga saham terdiri dari faktor fundamental dan faktor teknikal. Faktor fundamental ini sangat penting, karena harga saham sangat berhubungan dengan kemampuan perusahaan untuk menciptakan keuntungan di masa datang bagi pemegang saham. Sementara faktor teknikal yaitu harga saham dipengaruhi oleh pergerakan harga jual beli saham, jumlah saham yang diperdagangkan dan data lain yang bersumber dari pasar. Baik faktor fundamental maupun teknikal digunakan sebagai analisa kuantitatif untuk mengetahui data sebelumnya mengenai suku bunga, variabel-variabel ekonomi dan nilai saham. Analisa ini sangat penting bagi investor untuk membuat keputusan berinvestasi di saham.
\end{abstract}

\begin{abstract}
Eka Sri Wahyuni; The purpose of this study was to determine the factors - factors that affect stock prices and the development of Shari'ah in Indonesia. The method used in this library research. The results in this study is the movement of the stock price is affected by many factors. There are micro factors, there are also macro. In addition, the factors that affect stock price consists of fundamentals and technical factors. The fundamental factors are very important, because the share price is highly correlated with the company's ability to create future profits for shareholders. While technical factors are stock prices affected by movements in the share purchase price, number of shares traded and other data sourced from the market. Both fundamental and technical factors used as a quantitative analysis to determine the previous data on interest rates, economic variables and the value of stocks. This analysis is very important for investors to make a decision to invest in shares.
\end{abstract}

\section{Key Word: Stock Price Sharia, Islamic Shares Number of Transactions}

\section{PENDAHULUAN}

Kemajuan dan prestasi sebuah negara seringkali dinilai dari perkembangan perekonomiannya. Investasi dilakukan di berbagai bidang mulai dari Investasi nyata (real investment) secara umum melibatkan aset berwujud, seperti tanah, mesin-mesin, atau pabrik sampai dengan Investasi keuangan (financial investment) melibatkan kontrak tertulis, seperti saham biasa (common stock) dan obligasi (bond).

Hampir seluruh negara di dunia ini memiliki pasar modal (Capital Market) kecuali bagi negara-negara yang masih berbenah dan belum mampu melepaskan diri dari persoalan ekonomi dan politik yang begitu parah. Maka keberadaan pasar modal di negara tersebut dianggap belum begitu berjalan efektif. Ketidak efektifan ini dikarenakan adanya ketegangan politik yang berlangsung terus menerus tanpa ada penyelesaian, contohnya Negara Palestina, Suria dan beberapa negara lainnya.

Kemajuan pasar modal di suatu negara dijadikan tolak ukur untuk melihat kegairahan atau dinamisnya bisnis dalam suatu negara yang dapat memberikan nilai tambah pada 
pendapatan negara yang berkaitan dengan kebijakan fiskal yang sudah ditetapkan pemerintah yaitu dari segi pendapatan pajak (tax income).

Dalam praktiknya sistem keuangan Islam pun sudah menyiapkan sebuah wadah untuk umat yang ingin berinvestasi dalam bentuk investasi keuangan yang bisa memberikan jaminan kehalalan, dimana sistem keuangan Islam bukan sekedar transaksi komersial, tetapi harus Bentuk sistem keuangan atau lembaga keuangan yang sesuai dengan prinsip Islam ádalah terbebas dari unsur riba. Kontrak keuangan yang dapat dikembangkan dan dapat menggantikan sistem riba adalah mekanisme syirkah yaitu : musyarakah dan mudharabah (bagi hasil). Adapun bentuk kelembagaan yang menganut prinsip Islam antara lain: Perbankan Syari'ah, BPRS, Asuransi Syari'ah, Pegadaian Syariah, Pasar Modal Syari'ah, Dana Pensiun Syari'ah, Lembaga Keuangan Mikro Syari'ah, maupun lembaga keuangan publik Islam seperti lembaga pengelola zakat dan lembaga pengelola wakaf, Pasar Modal Syari'ah instrumennya antara lain saham syari'ah, sukuk dan Reksadana Syariah

Investasi syariah pada pasar modal syariah saat ini menjadi perhatian bagi investor yang ingin melakukan investasi pada sektor keuangan syariah. Berdasarkan Keputusan Dewan Komisioner Otoritas Jasa Keuangan Nomor KEP-24/D.04/2014 tentang Daftar Efek Syariah tercatat bahwa sampai dengan tahun 2014 terdapat 322 perusahaan yang sudah terdaftar memiliki efek syariah. ${ }^{1}$

Pembentukan fortofolio berupa instrumen syari'ah ini bertujuan untuk 1) memberikan keuntungan yang maksimum sesuai dengan yang diharapkan atau adanya return yang diharapakan (expected return), 2) Menciptakan resiko yang minimum, 3)Menciptakan continuity dalam bisnis.

Namun pada perkembangannya saham syari'ah ini belum begitu signifikan, ini bisa dilihat dari jumlah trasaksi syari'ah yang belum begitu banyak. Dan jumlah perusahaan yang terdaftar di Jakarta islamic Index(JII) juga cendrung masih sedikit. Pada saat ini terdapat hanya 46 perusahaan yang terdaftar di JII dan bila diambil contoh transaksi bulan januari untuk saham syari'ah hanya terdapat 18 transaksi saja dalam satu bulan berlangsung 2

Tabel 1. Perkembangan Kapitasisasi Pasar dan Jumah Perusahaan yang Tercatat di BEI

\begin{tabular}{rrrllllll} 
Date & Prev & Open & High & Low & Close & Change & \multicolumn{1}{c}{ Volume } \\
\hline $30-07-2015$ & 629.1040 & 632.6400 & 634.2340 & 627.3630 & 628.8950 & 0.2090 & $1,892,428,007,724$ \\
$29-07-2015$ & 628.6280 & 632.1800 & 637.5440 & 629.1040 & 629.1040 & 0.4760 & $1,721,432,141,410$ \\
$28-07-2015$ & 632.1420 & 629.9700 & 633.4840 & 626.8270 & 628.6280 & 3.5140 & $1,538,623,593,267$ \\
$27-07-2015$ & 646.9360 & 642.0500 & 645.0120 & 632.1420 & 632.1420 & 14.7940 & $1,430,307,909,363$ \\
$24-07-2015$ & 656.3370 & 653.0700 & 653.3650 & 646.0780 & 646.9360 & 9.4010 & $1,275,426,625,185$ \\
$23-07-2015$ & 658.3910 & 655.7800 & 657.3060 & 654.2820 & 656.3370 & 2.0540 & $1,455,517,365,750$ \\
$22-07-2015$ & 653.6520 & 655.9000 & 658.3910 & 650.6490 & 658.3910 & 4.7390 & $2,235,095,879,020$ \\
$15-07-2015$ & 655.9030 & 654.7300 & 656.4560 & 649.0200 & 653.6520 & 2.2510 & $1,442,363,533,247$ \\
$14-07-2015$ & 654.8150 & 658.5900 & 660.3980 & 653.5700 & 655.9030 & 1.0880 & $1,545,641,845,558$ \\
$13-07-2015$ & 648.7420 & 650.7700 & 655.6840 & 648.0380 & 654.8150 & 6.0730 & $1,416,902,737,478$ \\
$10-07-2015$ & 645.5850 & 650.1300 & 652.6960 & 645.4820 & 648.7420 & 3.1570 & $3,260,345,137,490$ \\
$09-07-2015$ & 653.2450 & 649.7500 & 650.0300 & 641.4440 & 645.5850 & 7.6600 & $1,745,882,597,475$ \\
$08-07-2015$ & 657.7210 & 661.3000 & 661.2990 & 652.7200 & 653.2450 & 4.4760 & $2,198,825,620,474$ \\
$07-07-2015$ & 661.3670 & 661.5900 & 663.3220 & 654.1160 & 657.7210 & 3.6460 & $1,766,038,936,285$ \\
$06-07-2015$ & 670.9340 & 664.1100 & 667.5750 & 660.0760 & 661.3670 & 9.5670 & $2,350,302,678,268$ \\
$03-07-2015$ & 662.4150 & 661.0500 & 671.0520 & 661.0300 & 670.9340 & 8.5190 & $1,650,697,192,840$ \\
$02-07-2015$ & 654.8080 & 657.8200 & 666.6620 & 657.8220 & 662.4150 & 7.6070 & $2,096,254,218,415$ \\
$01-07-2015$ & 656.9910 & 660.0600 & 661.6500 & 654.8080 & 654.8080 & 2.1830 & $1,601,833,442,020$
\end{tabular}

Berikut ini tabel performa saham-saham syariah yang tergabung dalam Jakarta Islamic Index selama enam bulan terakhir atau year to date: 
Tabel 2. Daftar Saham Syariah yang memeperoleh keuntungan (gain)

\begin{tabular}{|c|c|c|c|}
\hline selesces & 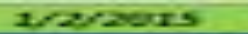 & eveleprass & 3 \\
\hline NKREA & 4.500 & 6000 & 300.5 \\
\hline unerst & 112,525 & $\cos 3000$ & $22-905=$ \\
\hline $1=-\cos$ & 7.000 & Is $3=0$ & 273003 \\
\hline iplat & 14.305 & 10.2000 & $=7-7 x=8$ \\
\hline SSMNS & 2,000 & $=915$ & 123125 \\
\hline urdine & 17,3000 & $19=350$ & $12-65 s$ \\
\hline Wract & 2406 & $x=20$ & xans \\
\hline Gavels & $7>+\infty$ & $1.0 x-10$ & 7900 \\
\hline$s=x$ & $7 \pi x 0$ & $1<000$ & 55005 \\
\hline Nophos & 3300 & 3940 & $4-528$ \\
\hline host & 5600 & 605 & $4 x 35$ \\
\hline Trosert & 2.560 & 20335 & 2028 \\
\hline $187^{*}$ & 3350 & 30000 & D.2: \\
\hline acto & $13 \times 150$ & $7 \geq 6000$ & $A D=00$ \\
\hline Nor & $x=4$ & 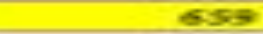 & -50 ors \\
\hline ESTDE & $1=5.5$ & 1,755 & -5900 \\
\hline ansern & 5,243 & $x \rightarrow 2 x$ & $-2 x \cos$ \\
\hline$\alpha=2=$ & $1=110$ & 1665 & -69208 \\
\hline Want & 20535 & 228000 & 7229 \\
\hline axer & 2.400 & 6.0135 & $-7.2 x=9$ \\
\hline mencer & $x, 4=0$ & 6.035 & $-2100 x$ \\
\hline $15 \mathrm{GP}$ & 1.000 & 1,6000 & $-7400>5$ \\
\hline werp & 24,6000 & 200.975 & -15425 \\
\hline matras & 15,500 & $13 \cdot 3000$ & - \pm 6.353 \\
\hline avericitu & $5-40$ & 402 & taxisas \\
\hline sechen & 3.500 & 2,000 & $-20-57$ \\
\hline Josmeas & 7.100 & 5.5000 & $22-50$ \\
\hline $30 \times 000$ & 3.500 & 2,255 & -23.2063 \\
\hline ADEloo & 2,0040 & 285 & $-24 \cdot 52=$ \\
\hline smacuat & $1,2,206$ & 12,00 is & -254003 \\
\hline frans & 5,921 & $4 x=5$ & $-2 x+203$ \\
\hline wrices & 3.575 & 2,520 & $-2858=$ \\
\hline
\end{tabular}

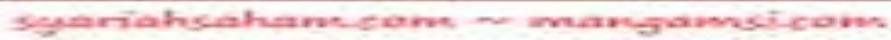

Dari tabel di atas, bisa dilihat dalam 6 (enam) bulan terakhit hanya terdapat 13 saham yang berhasil mencetak gain di tengah penurunan indeks JII dan juga IHSG. Ke-13 saham tersebut masing-masing adalah AKRA, UNVR, LPKR, LPPF, SSMS, UNTR, WSKT, SMRA, SILO, MPPA, ASRI, TLKM dan PTPP.

Berdasarkan latar belakang di atas, maka ada rumusan masalah yang dapat diambil sebagai kajian dalam penelitian ini adalah apa saja faktor - faktor yang mempengaruhi harga dan perkembangan saham syari'ah di Indonesia?

\section{JENIS PENELITIAN}

Adapun jenis penelitian yang digunakan dalam pengumpulan data adalah jenis pengumpulan studi kepustakaan (library research), dimana dalam hal ini penulis mengumpulkan data-data dari buku-buku, artikel, karya ilmiah yang ada relevansinya dengan permasalahan yang dibahas.

M. Nazir mengemukakan bahwa yang dimaksud dengan "Studi kepustakaan adalah teknik pengumpulan data dengan mengadakan studi penelaahan terhadap buku-buku, literaturliteratur, catatan-catatan, dan laporan-laporan yang ada hubungannya dengan masalah yang dipecahkan." 3

Penelitian kepustakaan merupakan jenis penelitian kualitatif yang pada umumnya tidak terjun ke lapangan dalam pencarian sumber datanya. Penelitian kepustakaan merupakan metode yang digunakan dalam pencarian data, atau cara pengamatan (bentuk observasi) secara mendalam terhadap tema yang diteliti untuk menemukan 'jawaban sementara' dari masalah yang ditemukan di awal sebelum penelitian ditindaklanjuti. Dengan kata lain penelitian kepustakaan merupakan metode dalam pencarian, mengumpulkan dan menganalisi sumber data untuk diolah dan disajikan dalam bentuk laporan penelitian kepustakaan. 
Untuk menganalisa data dan bahan yang penulis telah kumpulkan dari beberapa data dengan cara berpikir deskriptif dan induktif, yaitu metode analisa data dengan cara memberikan gambaran penelitian secara jelas dan terperinci yang diakhiri dengan menarik kesimpulan dimulai dari pernyataan umum menuju ke pernyataan khusus. Ini digunakan untuk kemudahan dalam menyimpulkan permasalahan yang dibahas.

\section{TINJAUAN LITERATUR \\ Saham Syariah}

Secara umum saham didefinisikan sebagai bukti penyertaan kepemilikan modal pada suatu perusahaan. Sunariyah dalam Abdul Aziz menjelaskan definisi saham sebagai berikut :

"Menurut Undang-Undang Perseroan yang belaku di Indonesia, saham adalah surat berharga yang dikeluarkan oleh perusahaan yang berbentuk perseroan terbatas (PT) atau yang biasa disebut emiten. Saham menyatakan bahwa pemilik saham tersebut adalah juga pemilik sebagian dari perusahaan tersebut. Dengan demikian apabila seorang investor membeli saham, maka ia pun menjadi pemilik dan disebut pemegang saham perusahaan".

Nurul Huda menjelaskan bahwa, saham merupakan surat bukti kepemilikan atas sebuah perusahaan yang melakukan penawaran umum (go public) dalam nominal atau pun persentase tertentu. Saham dapat juga diartikan surat berharga yang mempresentasikan penyertaan modal ke dalam suatu perusahaan. Sementara dalam prinsip Islam, penyertaan modal dilakukan pada perusahaan-perusahaan yang tidak melanggar prinsip-prinsip Islam, seperti bidang perjudian, riba, memproduksi barang yang diharamkan seperti bir dan lain-lain. Di Indonesia, prinsipprinsip penyertaan modal secara Islam tidak diwujudkan dalam bentuk saham Islam maupun non Islam, melainkan berupa pembentukan indeks saham yang memenuhi prinsip-prinsip Islam.4 Pengertian saham syariah tersebut ditegaskan oleh fatwa DSN Nomor: 40/DSNMUI/X/2003 yang menyatakan bahwa saham syariah adalah bukti kepemilikan atas suatu perusahaan yang memenuhi kriteria syariah dan tidak termasuk saham yang memiliki hak-hak istimewa.

Berdasarkan beberapa pengertian di atas dapat disimpulkan bahwa saham syariah adalah bukti penyertaan modal atau bukti kepemilikan atas suatu perusahaan yang dijalankan sesuai dengan prinsip syariah.

\section{JENIS - JENIS SAHAM}

Jenis-jenis saham yang beredar di Bursa Efek Jakarta (BEJ) dapat ditinjau dari beberapa segi, Darmadji dan Fakhruddin dalam Abdul Aziz menjelaskan jenis-jenis saham adalah sebagai berikut:

1. Ditinjau dari segi kemampuan dalam hak tagih atau claim :

a. Saham Biasa (common stock)

1. Mewakili klaim kepemilikan pada penghasilan dan aktiva yang dimiliki perusahaan

2. Pemegang saham biasa memiliki kewajiban yang terbatas. Artinya, jika perusahaan bangkrut, kerugian maksimum yang ditanggung oleh pemegang saham besarnya sama dengan investasi pada saham tersebut.

b. Saham Preferen (Preferred Stock)

1. Saham Preferen adalah saham yang memiliki karakteristik gabungan antara obligasi dan saham biasa, karena bisa menghasilkan pendapatan tetap (seperti bunga obligasi), tetapi juga bisa tidak mendatangkan hasil seperti yang dikehendaki investor.

2. Saham preferen serupa dengan saham biasa karena mewakili kepemilikan ekuitas dan diterbitkan tanpa tanggal jatuh tempo yang tertulis di atas lembaran saham tersebut dan membayar deviden. 
3. Persamaan saham preferen dengan obligasi adalah adanya claim atas laba dan aktiva sebelumnya, devidennya tetap selama masa berlakunya saham, dan memiliki hak tebus serta dapat dipertukarkan (convertible) dengan saham biasa.

c. Ditinjau dari cara peralihannya :

a) Saham Atas Unjuk (Bearer Stocks)

1) Ada "saham atas unjuk" tidak tertulis nama pemiliknya. Tujuannya adalah agar saham mudah dipindahtangankan dari satu investor ke investor lainnya.

2) Secara hukum, siapa yang memegang saham tersebut, maka orang tersebutlah yang diakui sebagai pemiliknya dan berhak untuk ikut hadir dalam RUPS (Rapat Umum Pemegang Saham).

b) Saham Atas Nama (Registered Stocks)

"Saham atas nama" merupakan saham yang ditulis dengan jelas siapa nama pemiliknya. Cara peralihannya harus melalui prosedur tertentu.

1. Speculative Stock

Saham suatu perusahaan yang tidak bisa secara konsisten memperoleh penghasilan dari tahun ke tahun, akan tetapi mempunyai kemungkinan penghasilan yang tinggi di masa mendatang, meskipun belum pasti.

2. Ditinjau dari kinerja perdagangan :

a) Blue-Chip Stocks

Saham biasa dari suatu perusahaan yang memiliki reputasi tinggi, sebagai leader market di industri sejenis, memiliki pendapatan yang stabil dan konsisten dalam membayar dividen.

b) Income Stocks

Saham dari suatu emiten yang memiliki kemampuan membayar dividen lebih tinggi dari rata-rata dividen yang dibayarkan pada tahun sebelumnya. Emiten yang seperti ini biasanya mampu menciptakan pendapatan yang lebih tinggi dan secara teratur membagikan dividen tunai. Emiten ini tidak suka menekan laba dan tidak mementingkan potensi.

d. Growth Stocks

\section{1) (Well-Known)}

Saham-saham dari emiten yang memiliki pertumbuhan pendapatan yang tinggi, sebagai leader di industri sejenis yang mempunyai reputasi tinggi.

2) (Lesser-Known)

Saham dari emiten yang tidak sebagai leader market dalam industri, namun memiliki ciri growth stock. Umumnya saham ini berasal dari daerah dan kurang populer di kalangan emiten.

e. Counter Cyclical Stockss

Saham yang tidak terpengaruh oleh kondisi ekonomi makro maupun situasi bisnis secara umum. Pada saat resesi ekonomi, harga saham ini tetap tinggi, di mana emitennya mampu memberikan dividen yang tinggi sebagai akibat dari kemampuan emiten dalam memperoleh penghasilan yang tinggi pada masa resesi.

Jenis saham terbaru yang diperdagangkan di BEI (Bursa Efek Indonesia), yaitu ETF (Exchange Trade Fund) merupakan gabungan reksadana terbuka dengan saham dan pembelian di bursa seperti halnya saham di pasar modal bukan di Manajer Investasi (MI). Adapun Exchange Trade Fund (EFT) dibagi 2, yaitu:

1. ETF index: menginvestasikan dana kelolanya dalam sekumpulan portofolio efek yang terdapat pada satu indeks tertentu dengan proporsi yang sama.

2. Close and ETF's Fund : diperdagangkan dibursa efek yang berbentuk perusahaan investasi tertutup dan dikelola secara aktif. 


\section{HASIL DAN PEMBAHASAN \\ PRINSIP DAN SYARAT INVESTASI SAHAM SESUAI SYARIAH}

Syarat suatu saham yang dikeluarkan oleh perusahaan dapat dikatakan syariah adalah sebagai berikut :

1. Jenis usaha, produk barang, jasa yang dibrikan dan akad serta pengelolaan perusahaan yang mengeluarkan saham (emiten) atau pengusaha publik yang menerbitkan saham tidak bole bertentangan dengan prinsip-prinsip syariah. Jenis kegiatan usaha yang bertentangan dengan prinsip-prinsip syariah, antara lain :

a) Perjudian dan permainan yang tergolong judi atau perdagangan yang dilarang.

b) Lembaga keuangan konvensional (ribawi), termasuk perbankan dan asuransi konvensional.

c) Produsen, distributor, serta pedagang makanan, minuman yang haram.

d) Melakukan investasi pada emiten (perusahaan) yang pada saat transaksi tingkat (nisbah) utang perusahaan pada lembaga keuangan ribawi lebih dominan dari modalnya.

2. Emiten atau Perusahaan Publik yang menerbitkan saham syariah wajib untuk menandatangani dan memenuhi ketentuan akad yang sesuai dengan syariah atas saham syariah yang dikeluarkan.

3. Emiten atau Perusahaan Publik yang menerbitkan saham syariah wajib menjamin bahwa kegiatan usahanya memenuhi prinsip-prinsip syariah dan memiliki Shariah Compliance Officer. (Fatwa DSN; No: 40/2003) menjelaskan identitas perusahaan yang dapat ikut dalam saham Islami mengajukan beberapa syarat yaitu :

a) Emiten (perusahaan) tersebut tidak berkaitan dengan riba.

b) Perusahaan tersebut tidak mem buat atau memproduksi barang atau jasa yang dilarang oleh syariah.

c) Perusahaan tidak bertindak eksploitatif secara berlebihan terhadap faktor-faktor produksi alam yag diberikan Allah.

d) Perusahaan tidak mempermainkan harga sekehendaknya, perusahaan tersebut tidak menghalangi terjadinya free market.

e) Perusahaan tersebut mempunyai sosial responsibility yang tinggi sehingga punya kepedulian terhadap umat, dan memiliki ethical behavior.

Berdasarkan syarat-syarat tersebut di atas, maka saham syariah harus sesuai prinsip dasarnya. Adapun prinsip dasar saham syariah bersifat sebagai berikut:5

1. Bersifat musyarakah jika ditawarkan secara terbatas.

2. Bersifat mudharabah jika ditawarkan kepada publik.

3. Tidak boleh ada pembeda jenis saham, karena risiko harus ditanggung oleh semua pihak.

4. Prinsip bagi hasil laba-rugi.

5. Tidak dapat dicairkan kecuali dilikuidasi.

\section{HARGA SAHAM SYARIAH}

Saham syariah adalah bukti penyertaan modal atau bukti kepemilikan atas suatu perusahaan yang dijalankan sesuai dengan prinsip syariah. Berdasarkan definisi saham syariah tersebut dapat dipahami bahwa, yang dapat menentukan suatu saham dikatakan syariah atau tidak, tergantung pada bagaimana perusahaan yang menerbitkan saham menjalankan perusahaannya, apakah dijalankan sesuai dengan prinsip-prinsip syariah atau tidak. Sedangkan harga saham adalah harga suatu saham yang terbentuk di bursa saham, yang ditentukan oleh kekuatan pasar, dalam artian tergantung kekuatan permintaan (penawaran beli) dan penawaran (penawaran jual).6 Pernyataan tersebut diperkuat oleh pendapat Ali Arifin yang menyatakan bahwa fluktuasi harga saham ditentukan oleh pelaku pasar dan ditentukan oleh permintaan dan penawaran saham yang bersangkutan di pasar modal.7 
Berdasarkan pemaparan tersebut, maka dapat disimpulkan bahwa harga saham syariah adalah harga atas suatu saham syariah yang terbentuk di bursa saham, yang ditentukan oleh pelaku pasar dan ditentukan oleh permintaan dan penawaran atas saham tersebut.

\section{FATOR-FAKTOR YANG MEMPENGARUHI HARGA SAHAM SYARIAH}

Pergerakan harga saham dipengaruhi oleh banyak faktor. Ada faktor yang bersifat mikro, ada juga yang bersifat makro. Yang dimaksud dengan faktor mikro adalah faktor-faktor yang dampaknya hanya terhadap beberapa jenis saham saja. Sedangkan faktor makro adalah faktor penyebab yang berdampak pada semua saham (keseluruhan bursa) termasuk juga perekonomian secara menyeluruh.8 Lebih jelas Alwi memaparkan tentang faktor-faktor yang mempengaruhi harga saham sebagai berikut: 9

1) Faktor Internal (Lingkungan mikro)

a) Pengumuman tentang pemasaran, produksi, penjualan seperti pengiklanan, rincian kontrak, perubahan harga, penarikan produk baru, laporan produksi, laporan keamanan produk, dan laporan penjualan.

b) Pengumuman pendanaan (financing announcements), seperti pengumuman yang berhubungan dengan ekuitas dan hutang.

c) Pengumuman badan direksi manajemen (management-board of director announcements) seperti perubahan dan pergantian direktur, manajemen, dan struktur organisasi.

d) Pengumuman pengambilalihan diversifikasi, seperti laporan merger, investasi ekuitas, laporan take over oleh pengakuisisian dan diakuisisi, laporan divestasi, dan lainnya.

e) Pengumuman investasi (investment annuncements), seperti melakukan ekspansi pabrik, pengembangan riset, dan penutupan usaha lainnya.

f) Pengumuman ketenagakerjaan (labour announcements), seperti negoisasi baru, kontrak baru, pemogokan, dan lainnya.

g) Pengumuman laporan keuangan perusahaan, seperti peramalan laba sebelum akhir tahun fiskal dan setelah akhir tahun fiskal, earning per share (EPS) dan dividen per share (DPS), price earning ratio, net profit margin, return on assets (ROA), dan lain-lain.

2) Faktor eksternal (Lingkungan makro)

Diantaranya antara lain :

a) Pengumuman dari pemerintah seperti perubahan suku bunga tabungan dan deposito, kurs valuta asing, inflasi, serta berbagai regulasi dan deregulasi ekonomi yang dikeluarkan oleh pemerintah.

b) Pengumuman hukum (legal announcements), seperti tuntutan karyawan terhadap perusahaan atau terhadap manajernya dan tuntutan perusahaan terhadap manajernya.

c) Pengumuman industri sekuritas (securities announcements), seperti laporan pertemuan tahunan, insider trading, volume atau harga saham perdagangan, pembatasan (penundaaan) trading.

d) Gejolak politik dalam negeri dan fluktuasi nilai tukar juga merupakan faktor yang berpengaruh signifikan pada terjadinya pergerakan harga saham di bursa efek suatu negara.

e) Berbagai isu baik dari dalam negeri dan luar negeri.

Selain itu, ada juga yang menyebutkan bahwa faktor-faktor yang mempengaruhi harga saham terdiri dari faktor fundamental dan faktor teknikal. 10

1) Faktor Fundamental

Dimana harga saham dipengaruhi oleh keadaan ekonomi, industri, dan perusahaan yang menerbitkan saham ybs. Faktor ini sangat penting, karena harga saham sangat berhubungan 
dengan kemampuan perusahaan untuk menciptakan keuntungan di masa datang bagi pemegang saham.

2) Faktor Teknikal

Dimana harga saham dipengaruhi oleh pergerakan harga jual beli saham, jumlah saham yang diperdagangkan dan data lain yang bersumber dari pasar. Baik faktor fundamental maupun teknical digunakan sebagai analisa kuantitatif untuk mengetahui data sebelumnya mengenai suku bunga, variabel-variabel ekonomi dan nilai saham. Analisa ini sangat penting bagi investor untuk membuat keputusan berinvestasi di saham.

Faktor mikro dan makro atau pun faktor fundamental dan faktor teknikal pada dasarnya memiliki maksud dan tujuan yang sama, hanya terdapat perbedaan dalam istilah saja.

Sama halnya dengan harga saham pada umumnya, pergerakan harga saham syariah juga dipengaruhi oleh faktor-faktor tersebut.

\section{KESIMPULAN}

Berdasarkan pembahasan di atas dapat disimpulkan bahwa faktor-faktor yang mempengaruhi harga dan perkembangan saham syariah di Indonesia terdiri dari faktor yang bersifat mikro, ada juga yang bersifat makro. Selain itu, faktor-faktor yang mempengaruhi harga saham terdiri dari faktor fundamental dan faktor teknikal. Faktor fundamental ini sangat penting, karena harga saham sangat berhubungan dengan kemampuan perusahaan untuk menciptakan keuntungan di masa datang bagi pemegang saham. Sementara faktor teknikal yaitu harga saham dipengaruhi oleh pergerakan harga jual beli saham, jumlah saham yang diperdagangkan dan data lain yang bersumber dari pasar. Baik faktor fundamental maupun teknical digunakan sebagai analisa kuantitatif untuk mengetahui data sebelumnya mengenai suku bunga, variabelvariabel ekonomi dan nilai saham. Analisa ini sangat penting bagi investor untuk membuat keputusan berinvestasi di saham.

\section{SARAN}

Pergerakan harga saham yang dipengaruhi oleh banyak faktor menjadi acuan bagi pelaku pasar di bursa saham dalam memperhatikan tingkat permintaan dan penawaran terhadap saham syariah itu sendiri. Melihat faktor-faktor yang mempengaruhi harga saham syariah tersebut, maka seyogianya para pelaku di bursa saham dapat menjadikan faktor-faktor tersebut sebagai pertimbangan dalam mengambil keputusan berinvestasi saham syariah dengan tepat.

\section{DAFTAR PUSTAKA}

Arifin, Ali. 2001. Membaca Saham. Yogyakarta: Andi.

Asnaini, dkk. 2012. Manajemen Keuangan. Yogyakarta: Teras.

Aziz, Abdul. 2010. Manajemen Investasi Syariah. Bandung: Alfabeta.

Daftar Efek Syariah. (http://www.ojk.go.id diakses pada 23 januari 2015).

Denies , Ade Kusumah. 2012. Pengaruh Return On Investment (ROI), Earning Per Share (EPS), dan Deviden Per Share (DPS) Terhadap Harga Saham Perusahaan Pertambangan Yang Terdaftar di Bursa Efek Indonesia (BEI) periode 2008-2010. Jurnal Nominal, Volume I No.I, Fakultas Ekonomi Universitas Negeri Yogyakarta, (tahun 2012).

Dewan Syariah Nasional MUI-Bank Indonesia. 2006. Himpunan Fatwa Dewan Syariah Nasional MU. Ciputat: Gaung Persada. 
Dewimayasari. Faktor - Faktor yang Mempengaruhi Pergerakan Harga Saham. (http: // dewimayasari. wordpress. com/ 2010/ 11/ 12/ topik - faktor -\% E2\%80\%93-faktoryang-mempengaruhi-pergerakan-harga-saham/, diakses pada 12 September 2012).

Fahmi, Irham. 2013. Analisis Laporan Keuangan.Bandung: Alfabeta.

Faktor - Faktor yang Mempengaruhi Harga Saham. (http:// sahamidx. blogdetik. com/ 2012/ 08/30/13/ diakses pada tanggal 18 September 2014)

Nazir, Metode Penelitian, (Jakarta, Ghalia Indonesia, cet.ke-5, 2003).

Nurul Huda \& Mohamad Heykal. 2010. Lembaga Keuangan Islam: Tinjauan Teoritis dan Praktis. Jakarta: Kencana.

Nurul Huda \& Mohamad Heykal. 2010. Investasi pada Pasar Modal Syariah. Jakarta: Kencana.

Widiatmodjo, Sawidji. 2004. Cara Cepat Memulai Investasi Saham Bagi Pemula.Jakarta: Elex Media Komputindo. 